\title{
Parental styles and coparenting in families with children with autism: cluster analysis of children's behavior
}

\author{
Estilos parentais e coparentalidade em familias \\ de crianças com autismo: análise de perfis \\ de comportamento infantil
}

\author{
João Rodrigo Maciel PORTES1 (iD) 0000-0003-2512-4491 \\ Mauro Luís VIEIRA2 (iD) 0000-0003-0541-4133 \\ Carolina Duarte de SOUZA ${ }^{3}$ (D) 0000-0003-3555-1120 \\ Erikson KASZUBOWSKI ${ }^{4}$ (D) 0000-0001-5481-1755
}

\begin{abstract}
Research on atypical developing parenting usually investigates only the mother. This happens even if the investigation outcome points to the influence of the parenting style and the child's relationship with the father on his/her perception of well-being. This investigation aimed to understand the relationships between the behavior of children with Autistic Spectrum Disorder, parenting styles and coparenting of 45 biparental families with children aged, on mean, 59 months, according to defined profiles based on children's behavioral differences. Data was reviewed by hierarchical clustering. Among the four profiles found, those characterized by behavioral difficulties showed more authoritarian/permissive
\end{abstract}

$\because \mathrm{Tr}$

1 Universidade do Vale do Itajaí, Escola de Ciências da Saúde, Curso de Psicologia. R. Uruguai, 458, Centro, 88302-901, Itajaí, SC, Brasil. Correspondence to: J.R.M. PORTES. E-mail: <joaorodrigo@univali.br>.

2 Universidade Federal de Santa Catarina, Departamento de Psicologia, Programa de Pós-Graduação em Psicologia. Florianópolis, SC, Brasil.

3 Universidade Federal de Santa Catarina, Curso de Graduação em Psicologia, Departamento de Psicologia. Florianópolis, SC, Brasil.

${ }^{4}$ Universidade Federal de Santa Catarina, Departamento de Psicologia, Serviço de Atenção Psicológica. Florianópolis, SC, Brasil. Supoort: Coordenação de Aperfeiçoamento de Pessoal de Nivel Superior (Finance Code 001) and Conselho Nacional do Desenvolvimento Científico e Tecnológico (Process no 303459/2015-8).

Article based on doctoral thesis of J.R.M. PORTES, entitled "Relações entre estilos parentais, coparentalidade e características de comportamento de crianças com transtorno do espectro autista". Universidade Federal de Santa Catarina, 2018.

$\boldsymbol{\nabla} \mathbf{v} \boldsymbol{v}$

How to cite this article

Portes, J. R. M., Vieira, M. L., Souza, C. D., \& Kaszubowski, E. (2020). Parental styles and coparenting in families with children with autism: cluster analysis of children's behavior. Estudos de Psicologia (Campinas), 37, e190143. http://dx.doi.org/10.1590/1982-0 275202037 e190143 
parenting styles and negative impacts on coparenting; profiles with greater prosociability had a more authoritative parenting style and better coparenting quality. The behavioral assessment of children should drive the formulation of interventions/public policies to promote positive parenting in this population.

Keywords: Autism spectrum disorder; Child behavior; Family relations; Parenting.

\section{Resumo}

Pesquisas sobre parentalidade em desenvolvimento atípico costumam investigar apenas a mãe, mesmo seus resultados apontando para a influência do estilo parental e do relacionamento com o pai na percepção de bem-estar da criança. Esta pesquisa objetivou compreender as relações entre o comportamento de crianças com Transtorno do Espectro Autista, os estilos parentais e o relacionamento coparental de 45 familias biparentais com crianças com idade média de 59 meses em função dos perfis definidos a partir das diferenças comportamentais infantis. Os dados foram analisados por clusterização hierárquica. Dentre os quatro perfis encontrados, os que se caracterizavam por dificuldades comportamentais apresentaram estilos parentais mais autoritários/permissivos e impactos negativos na coparentalidade; aqueles com maior prossociabilidade evidenciaram um estilo parental mais autoritativo e uma melhor qualidade na coparentalidade. A avaliação comportamental da criança deve pautar a formulação de intervenções/políticas públicas de promoção de parentalidade positiva nessa população.

Palavras-chave: Transtorno do espectro autista; Comportamento infantil; Relações familiares; Poder familiar.

Autism Spectrum Disorder (ASD) is characterized mainly by persistent impairments in reciprocal social communication and social interaction, showing also restricted and repetitive patterns of behavior, interests or activities. The term spectrum refers to levels and dimensions of variability in the manifestation of autism symptoms; they are associated with impairment in the individual's adaptive behavior (American Psychological Association [APA], 2014). Among the clinical manifestations, the highest prevalence of behavioral problems stands out among children with ASD when compared to children with other disabilities (Totsika, Hastings, Emerson, Lancaster, \& Berridge, 2011); communication difficulties (Pereira, Canal, Corrêa Silva, \& Pimentel, 2018) and changes in routine and aggressiveness associated with ASD are pointed out in research papers as being the most challenging for parents (Siu et al., 2019).

In line with this scenario, studies show that the behavior of children with ASD can contribute to increase parental stress, especially maternal stress when compared to the stress symptoms reported by parents of children with typical development or with other disabilities (Baykal, Karakurt, Çakır, \& Karabekiroğlu, 2018). In addition, according to Dunn, Burbine, Bowerse, and Tantless-Dunn (2001), the increase in parental stress levels is proportional to the increase in the intensity of occurrence of disruptive behaviors. This data is relevant given the estimate of the World Health Organization (World Health Organization, 2017) that 1 in 160 children worldwide has ASD and that among 16,386,239 children aged 0 to 4 years, 114,704 could be diagnosed with ASD in Brazil (Fombonne, 2010).

Mothers, and especially their parental stress, have been the focus of most research on parenting in connection with atypical development (Davys, Mitchell, \& Martin, 2017; Faro, Santos, Bosa, Wagner, \& Costa Silva, 2019). The results point to the influence, among other factors, of the quality of the relationship with the partner (Bourke-Taylor, Howie, \& Law, 2010) and the mother's parenting style (Braunstein, Peniston, Perelman, \& Cassano, 2013) for their perception of well-being and stress. There is a gap in this scenario (stress, well-being and ways of dealing) in relation to paternal parenting with children with atypical development due to the scarce literature available on the subject (Boyd, lacono, \& McDonald, 2019; Davys et al., 2017; Hirsch \& Paquin, 2019).

Among the studies on ASD that include the father, several investigations suggest that the main source

2 of support to deal with the ASD challenges is the coparental partnership, which points to the importance of 
co-parenting in this context (Hall \& Graff, 2011; Kersh, Hedvat, Hauser-Cram, \& Warfield, 2006). This can be understood as the relationship between the parental figures regarding education, training and decisions about their children's lives; the quality of this relationship is measured by the degree of joint and reciprocal involvement of parents in the way they will raise their children (Feinberg, 2003). The quality of this relationship has been identified as an important developmental factor in children with typical development (Frosch, Schoppe-Sullivan, \& O’Banion, 2019).

In the realm of ASD, Hirsch and Paquin (2019) concluded that the development of a shared parental strategy to face the challenges encountered can assist in the management of the child's behavior. In addition, for the investigators, parents who already shared tasks before their child's birth usually face the challenges of ASD better than those who perceived to have a low-quality coparental relationship.

Regarding actual coparenting, some studies have found important relationships with different variables such as parental stress and parental self-efficacy. Maternal and paternal perception of the quality of the coparental relationship was also pointed out by May, Fletcher, Dempsey, and Newman (2015) as being a mediator between parental stress and the perceptions of parental self-efficacy in ASD. The survey results also pointed out that fathers and mothers who reported having a negative perception of coparental relationships but had a positive perception of their parental self-efficacy in ASD, nevertheless, exhibited high levels of parental stress. Along the same line, Sim, Cordier, Vaz, Netto, and Falkmer (2017) found that parental figures who perceived a negative impact of ASD diagnosis on their coparental relationship were more likely to be stressed than those who reported having a good coparental relationship. Similarly, Thullen and Bonsall (2017) found inverse associations between agreement on parental care, support received and parental stress.

Recently, the study by May, George, Fletcher, Dempsey, and Newman (2017) revealed that their child's ASD diagnosis made the parents give greater importance to the coparental relationship, together with each partner support and communication quality, as well as the distribution of parental tasks. Similar results on the couple's mutual support were also found in the Brazilian study on coparenting in hetero-affective two-parent families with children with ASD (Sifuentes \& Bosa, 2010). In the study by Hirsch and Paquin (2019), participants described their relationship with their parents individually in different ways, with emphasis on descriptions of how parents make parental decisions, share a similar coparental strategy, but have their own parenting styles (different from each other). The parenting style is formed by the set of parenting educational practices, which are the parenting strategies for socializing their children; these strategies are characterized by techniques of behavioral control and reinforcement (Baumrind, 1991). Based on the dimensions used by MacCoby and Martin (1983), Baumrind (1991) classified parental behavior into four styles: democratic-reciprocal (high levels of parental demand and responsiveness - parents who have assertive skills, capable of directing their children's behavior, but who also allow the child to stand and share his/her disagreements); authoritarian (high demands and low parental responsiveness - parents who control their child's behavior, through arbitrarily imposed rules); permissive (low levels of demand and high levels of parental responsiveness - tolerant parents who act with great affection and receptivity to the child's wishes and do not use punishment) and rejector-negligent (low levels of parental demand and responsiveness - parents who show indifference in their parental role). The behavioral characteristics of a child with ASD can negatively interfere with parenting styles, increasing parental control and protection behavior (Woolfson \& Grant, 2006). In turn, negative parenting styles can increase the behavioral problems of the child with ASD (Gau et al., 2010).

The investigation by Riany, Cuskelly, and Meredith (2017) compared parenting styles, parent-child relationships and social support in Indonesian parents of children with and without ASD. The results showed that the parents of children with ASD were more authoritarian than the parents of children with typical development, who in turn were more authoritative. In a new study with families who have children with ASD in Indonesia, Riany, Cuskelly, and Meredith (2019) found that socioeconomic status is an important 
predictor of parenting styles, and specifically in this investigation it was found that the higher the parents' income the more they used the authoritarian style.

These studies provide clues about how coparenting and parenting style work in hetero-affective twoparent families with children with ASD. However, no research was retrieved that investigates coparenting and parenting style due to the diversity of children with ASD behavior. Therefore, this investigation aimed to understand the relationships between the children with ASD behavior, parenting styles and the coparental relationship. To this end, profiles of behavior of children with ASD were defined in the first place and then the coparental relationship and the parental style of their parents according to the children's behavioral differences were described.

\section{Method}

\section{Participants}

A total of 45 fathers $\left(M_{\text {age }}=36.36\right.$ months, $\left.S D=7.19\right)$ and 45 mothers $\left(M_{\text {age }}=31.78\right.$ months, $\left.S D=5.92\right)$, totaling 90 participants were included. As an inclusion criterion, couples should have a son or daughter in the age group of 3 to 7 years, with a diagnostic report indicating ASD according to the Diagnostic and Statistical Manual of Mental Disorders-5th (DSM-5) criteria (APA, 2014), being attended by the service in which the investigation's participants were recruited. These fathers and mothers should also have had this focal child after they were 18 years of age and have lived together for at least six months. In contrast, the exclusion criteria adopted were parents which intellectual disability or some serious and persistent mental disorder.

The children's ages ranged between 36 and 92 months $\left(M_{\text {age }}\right.$ in months $\left.=59.07, S D=17.35\right)$. Regarding the child's gender, $86.7 \%(n=39)$ were male. Most families were nuclear $(n=34)$ (biological parents of all children). The couple's education level varied somewhat among the participants: there was a greater concentration of complete high school education for fathers, $42.2 \%(n=19)$, and for mothers, $44.4 \%(n=20)$. All participating fathers were employed, except for two who indicated to be unemployed. Regarding mothers, $42.2 \%(n=19)$ indicated that they were housewives.

\section{Instruments}

Data were collected using a Sociodemographic Questionnaire (SQ), the Coparenting Relationship Scale (CRS), the Parenting Styles and Dimensions Questionnaire - Short Form (PSDQ) and the Strengths and Difficulties Questionnaire (SDQ). The SQ was developed by researchers associated with the Center for Studies and Research in Child Development (Núcleo de Estudos e Pesquisa em Desenvolvimento Infantil) and was adapted to the specificities of the population to be investigated in this study. It contains questions concerning variables about family data such as age, education and parents' work.

The adaptation to Brazil (Carvalho et al., 2018) of the Escala de Relação Coparental (Coparenting Relationship Scale) consists of 35 items, assessed by a seven-point scale ranging from not true (0) to completely true (6), except for the Exposure to Conflict subscale, in which the response categories range from never (0) to very frequently (6). Its seven subscales are: (a) Coparental agreement (agreements or disagreements regarding parenting practices and issues related to child rearing); (b) Division of work (satisfaction with the contributions and the involvement of the partner in raising their children); (c) Coparental support (perception of the support received from the partner), (d) Support to the partner's parenting (perception of their own positive attitudes towards the partner's parenting), (e) Coparental sabotage (perception of the partner's 4 behaviors that aim at undermine their parenting or relationship with the child); and (f) Exposure to conflicts 
(how much the parents expose the child to their disagreements about how to raise their children) and (g) Coparental proximity (degree to which coparenting can contribute to increase intimacy and strengthen the couple's relationship).

The Portuguese version of the PSDQ (Pedro, Carapito, \& Ribeiro, 2015) has two versions, one for the mother and the other for the father. The two versions are composed of the same items, differing only in the construction of the sentence in relation to the respondent's gender. The parent answers questions about how he/she behaves with regard to his/her child divided into three dimensions: authoritative, authoritarian and permissive. The Brazilian version of the SDQ (Fleitlich, Cartázar, \& Goodman, 2000) evaluated children's behavior using five subscales (emotional symptoms, conduct problems, hyperactivity, problems with peer relationships and prosocial behavior) and 25 items answered by one three-point Likert scale (false, more or less true and true) for the child's behavior in the last six months.

\section{Procedures}

Recruitment was carried out at a Specialized Rehabilitation Center that provides assistance to eleven municipalities in a region in southern Brazil and will preferably assist children with ASD aged from 0 to 12 years. This is a service defined as an "outpatient care specialized in rehabilitation that performs diagnosis, treatment, concession, adaptation and maintenance of assistive technology, constituting a reference for the health care network in the territory" (Ministério da Saúde, 2012, Art. 19).

The answers' collection was carried out at a time and place preferred by the participants. After the participants signed the Free and Informed Consent Form, an investigator applied the questionnaires with the participants. The survey was conducted based on ethical parameters, in compliance with Resolution $\mathrm{n}^{\circ}$ 466, of December 12, 2012 of the National Health Council. This research is part of the project "Father's involvement in the contemporary family context II", approved by the Ethics Committee in Research with Humans at the Universidade Federal de Santa Catarina, under n 1.514.798.

\section{Data analysis}

The answers to the questionnaires were tabulated and analyzed with the aid of the Free Statistical Software R (version 3.3.2). The hierarchical clustering technique was used with the minimization of variance criterion (Ward's criterion) of the scoring elements' Euclidean distance (James, Witten, Hastie, \& Tibshirani, 2013) in order to identify the different profiles of the children in the sample; the children were distributed in subgroups according to the abilities and difficulties of their behavior, based on the values obtained from the SDQ. Subsequent to the identification of the profiles by the SDQ clusters, the descriptive statistics of the Questionário de Dimensões e Estilos Parentais (Parenting Styles and Dimensions Questionnair) and Escala de Relação Coparental (Coparenting Relationship Scale) variables were computed according to the children's behavior profiles identified by the clusters obtained in the hierarchical analysis.

\section{Results}

The reviews performed showed four profiles of children's behavior. The mean value of the factors of the abilities and behavioral difficulties of each profile can be seen in Table 1. To make the comparison between profiles more intuitive, the scores were centralized and rescheduled based on the mean and standard deviation of the entire sample (James et al., 2013). The children's behavior profiles were related to the descriptive statistics of coparenting and parenting styles, the results of which are shown in Table 2 and Figure 1. 
Table 1

Mean of the standardized scores according to the cluster of the dimensions of the children's behavior

\begin{tabular}{lccc}
\hline \multirow{2}{*}{ Profiles } & \multicolumn{3}{c}{ Child } \\
\cline { 2 - 4 } & Frequency $(n)$ & Behavioral difficulties & Prosociability \\
\hline 1 & 13 & 0.86 & 0.68 \\
2 & 7 & -0.36 & -0.54 \\
3 & 16 & -0.73 & 0.58 \\
4 & 9 & 0.34 & -1.59 \\
\hline
\end{tabular}

Table 2

Mean of the standardized scores of the dimensions of the Coparenting and the Parental Styles

\begin{tabular}{|c|c|c|c|c|c|c|c|c|c|c|c|}
\hline \multirow[b]{2}{*}{ Profiles } & \multirow[b]{2}{*}{$\begin{array}{l}\text { Parental } \\
\text { figure }\end{array}$} & \multicolumn{7}{|c|}{ Coparenting } & \multicolumn{3}{|c|}{ Parenting Style } \\
\hline & & Agreement & Proximity & Support & Acknowledge & $\begin{array}{c}\text { Task } \\
\text { Division }\end{array}$ & Conflict & Sabotage & Authoritative & Authoritarian & Permissive \\
\hline \multirow[t]{2}{*}{1} & Mother & -0.47 & 0.06 & -0.14 & -0.28 & 0.02 & 0.32 & 0.34 & 0.18 & -0.22 & 0.26 \\
\hline & Father & -0.20 & -0.06 & 0.16 & 0.10 & -0.15 & 0.50 & 0.45 & 0.02 & 0.20 & 0.57 \\
\hline 2 & Mother & 0.08 & -0.27 & 0.15 & -0.09 & 0.33 & 0.31 & -0.28 & 0.02 & -0.24 & 0.29 \\
\hline \multirow[t]{2}{*}{3} & Mother & 0.12 & 0.18 & -0.02 & -0.01 & -0.32 & -0.37 & -0.18 & -0.01 & -0.06 & -0.26 \\
\hline & Father & 0.12 & 0.13 & 0.23 & 0.28 & -0.17 & -0.48 & -0.22 & 0.22 & -0.37 & -0.58 \\
\hline \multirow[t]{2}{*}{4} & Mother & 0.40 & -0.19 & 0.12 & 0.50 & 0.28 & -0.05 & 0.05 & -2.55 & 6.22 & -1.42 \\
\hline & Father & -0.16 & -0.55 & -0.62 & -0.43 & 0.39 & 0.23 & -0.15 & -7.95 & 3.97 & 1.83 \\
\hline
\end{tabular}

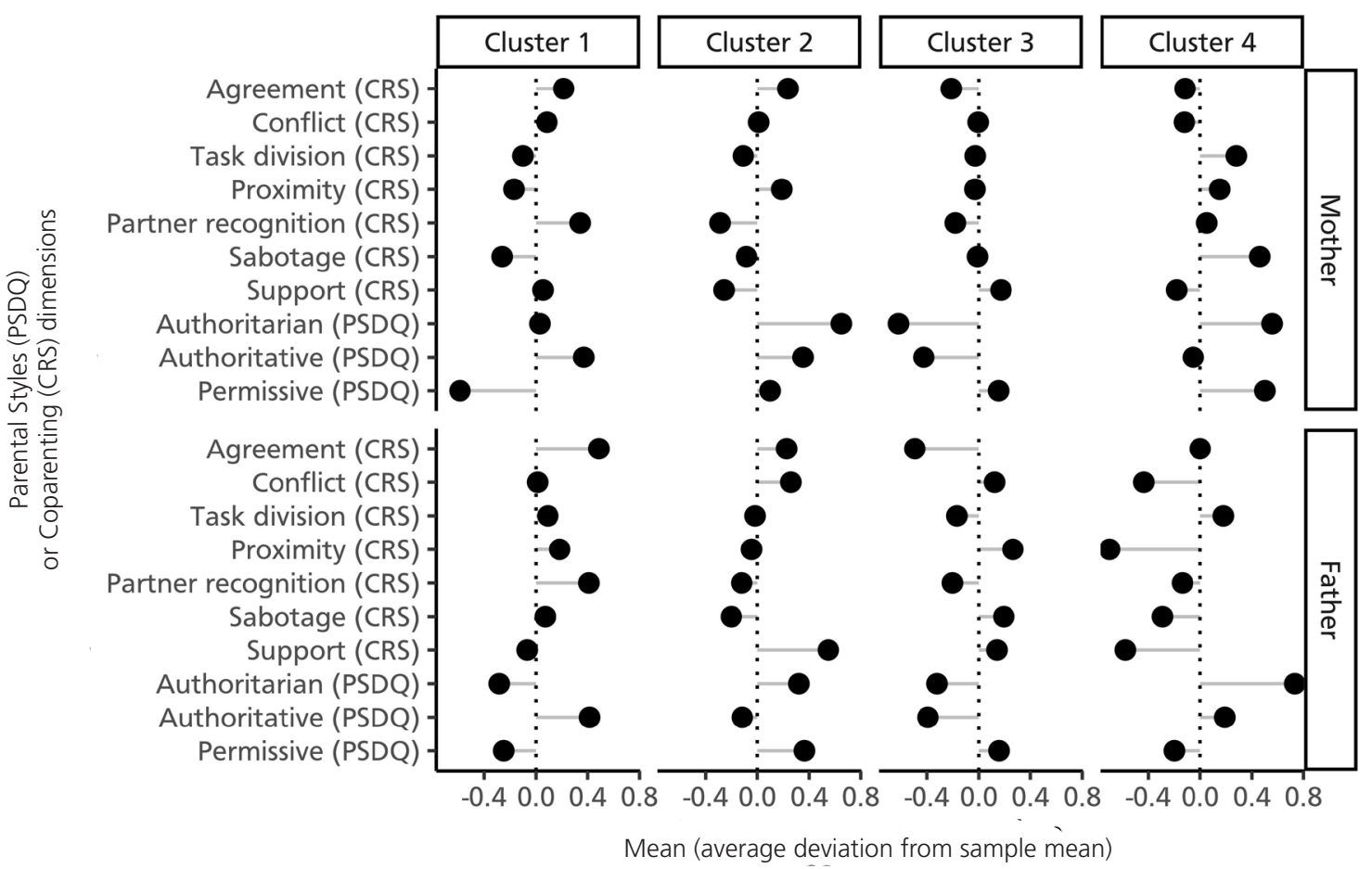

Figure 1. Profiles of fathers and mothers of each cluster in relation to the dimensions of Parental Style (PSDQ) and Coparenting (CRS).

Note: The variables were centered on the sample mean, identified by the vertical dotted line. The black circles indicate the mean deviation. 
Profile 1 represents children who have many behavioral difficulties while also exhibiting skills in prosocial behavior. In this profile, children exhibit the highest rates of behavior problems and both fathers and mothers agree that the coparental relationship is crossed by high rates of conflict and sabotage. Mothers show low levels of agreement, acknowledgement of their partner's parenting and support, and higher levels, mainly of conflict and sabotage, together with proximity and division of tasks. Fathers exhibit negative mean in agreement, proximity and division of tasks and higher rates of conflict and sabotage - and these are the highest mean among the four profiles. Nevertheless, they show a reasonable level of support and recognition of their partner's parenting.

Regarding the parenting style, mothers perceive their parenting style as permissive, followed by the authoritative style and with negative levels of the authoritarian style. On the other hand, fathers also showed a predominance of the permissive style, but the authoritarian style also had a higher mean, finally followed by the authoritative style.

Profile 2 refers to children with borderline indicators of behavioral and prosocial skills difficulties. The difficulty in expanding children's prosocial skills may be related to the divergent perception of fathers and mothers in relation to coparenting. The mothers showed negative mean in proximity, sabotage, recognition of the partner's parenting and higher levels of conflict, division of tasks, support and parental agreement. On the other hand, fathers exhibited the lowest levels of conflict and the highest proximity in the relationship when compared to the other profiles. This result is different from that presented by mothers with this profile. The fathers also show higher rates of agreement and division of tasks and negative mean in terms of support, sabotage and acknowledgement of the partner's parenting.

The mothers presented results similar to those of the mothers of the first profile regarding the parenting style, with higher mean for the permissive and authoritative style and negative mean for the authoritarian style. Fathers exhibited the highest mean e for the authoritative style when compared to the other profiles. In addition, they also showed a high mean for the permissive style and a negative index for the authoritarian style.

Profile 3 is composed of children with greater prosocial behavior skills and few behavioral difficulties and it was the profile that included the largest number of children. These children characteristics seem to influence the perception of the parents' coparental relationship, because mothers and fathers have the lowest rates of conflict when compared to other profiles. Mothers have negative mean in sabotage, division of tasks; close to zero in support and recognition of the partner's parenting and higher mean in agreement and proximity, the latter being the highest among the four profiles. Fathers agree with their partners with higher levels in the agreement and proximity dimensions but differ in terms of support and recognition of the partner's parenting because they exhibit positive mean. Fathers exhibit the lowest rates of conflict, sabotage and division of tasks when compared to the other profiles.

The mothers of this profile showed the lowest index of permissive parenting style when compared to the other profiles and also presented negative indexes for the authoritarian and authoritative styles, the latter being very close to zero, which suggests being within the mean. Fathers revealed the lowest levels of self-perception in permissive and authoritarian styles when compared to the four profiles and showed positive rates for the authoritative style.

Finally, profile 4 represents children with limitations in prosocial behavior and stronger indicators of behavioral difficulties. There were divergences in the couple's perception of coparenting, especially with regard to conflict, support, parental agreement and recognition of the partner's parenting. Mothers presented negative mean only in the proximity and conflict dimensions, with high rates of agreement and recognition of the partner's parenting (the highest when compared to the other profiles) and positive mean in the dimensions support, division of tasks and sabotage. On the other hand, fathers stood out due to the negative levels of proximity, support and acknowledgement of the partner's parenting - the lowest when compared to the 
four profiles. Fathers also showed negative mean for agreement and sabotage. The dimensions with the highest indexes are conflict and division of tasks, the latter being the highest when compared to the other profiles. Both mothers and fathers demonstrated a perception of the parenting style with the lowest levels of the authoritative style and the highest mean for the authoritarian style compared to the other profiles. In addition, they also showed a negative mean of the permissive style.

\section{Discussion and Conclusion}

The aim of this survey was to investigate the behavior of children with Autism Spectrum Disorder, parenting styles and coparental relationships. The results obtained revealed that the profile of children with greater behavioral difficulties had parents with more authoritarian or permissive parenting styles and with impacts on the coparental relationship, such as increased conflicts and partner's sabotage, as evidenced in the first profile. However, in profile four, despite the children having many behavioral difficulties, the parents recognized the partner's efforts in the exercise of parenting. On the other hand, in children who had greater skills in prosocial behavior, couples showed a tendency to adopt an authoritative parenting style and with higher quality in the coparental relationship, accompanied by increased proximity and agreement in parenting practices.

A relevant feature of the first profile is that children exhibit the highest rates of behavior problems and the couple agrees that the coparental relationship is crossed by high rates of conflict and sabotage. Generally, childcare with ASD is attributed to a higher level of parental stress and consequently a negative parental relationship with higher levels of conflict and disagreement (Baykal et al., 2018; Dunn et al., 2001; Sim et al., 2017). Over time, a balance in parental parenting practices is required and this depends on their ability to manage stress and work together to maintain a high level of care for their ASD child (Hirsch \& Paquin, 2019; Thullen \& Bonsall, 2017). This profile is also characterized by the predominance of permissive parenting style in the couples' view of their style; these families have the habit of fulfilling all the child's wishes with a low level of demand and that can corroborate the increase of the child's emotional symptoms, such as those related to anxiety and intense crying.

In the second profile, children were described with borderline indicators of behavioral difficulties and prosocial skills. In this profile, there was a disagreement within the couple on the coparental proximity dimension; mothers exhibited negative means and fathers positive means. In addition, these couples showed negative means about the acknowledgement of the partner's parenting. This difference in the perception of the couple's members about the proximity of the partner in the coparental relationship together with a lack of appreciation of their efforts to care for the child with ASD may be risk factors for the increase in the child's behavior problems.

The predictive study by Mosmann, Costa, Einsfeld, Silva, and Koch (2017) with fathers and mothers of children with typical development found that the variable "acknowledgement of the partner's parenting" is a predictor of internalizing symptoms (relationship problems with the partner and emotional symptoms) and externalizing symptoms (hyperactivity, conduct problems), indicating that, the lower the partner's recognition, the greater the emotional and behavioral symptoms in the children. In this sense, in the absence of such recognition, there is a tendency for partners to point out their partner's mistakes and this friction in the coparental relationship reverberates in the increase of the child's behavior problems and in the other systems, both marital and parental.

Regarding parenting styles, mothers in this second profile have a tendency to use more of the permissive style, which evidences an upbringing without demands and in the fulfillment of all the child's wishes. On

8 the other hand, the parents of this profile demonstrate a predominance of the authoritative style. Baumrind 
(1991) revised his theoretical model and called the authoritative style democratic reciprocal. In this style are found parents who have high levels of demand and responsiveness. These parents have assertive skills and establish clear and consistent rules and reinforce the child's positive behaviors and take action to adjust negative behaviors.

Profile 3 stands out for having the largest number of subjects, which was not expected since children with ASD do not usually have high levels of social skills. A Brazilian study conducted by Camargo and Bosa (2012) analyzed the profile of social competence of a preschool child with autism, in the ordinary school compared to a child with typical development and investigated the influence of the school environment (classroom or courtyard) in the profile of such competence of both children. The child with autism showed a higher frequency of cooperative and social assertion behaviors and a lower frequency of aggression and disorganization of the self in the school courtyard. Couples of this profile show higher mean concerning parental practices and coparental proximity. The greater agreement on parental care and the greater support received were associated with reduced parental stress (May et al., 2017; Sifuentes \& Bosa, 2010; Thullen \& Bonsall, 2017).

When analyzing the parenting styles of this group, it can be observed that both fathers and mothers have an authoritative parenting style, that is, there is a high level of affection accompanied by the ability to control the child's behavior problems. Among the few investigations reporting results in connection with the authoritative style in families of children with ASD, we should point out the comparative study between mothers of children with ASD and children with typical development in the Netherlands and Belgium. Mothers of children with ASD had higher scores on positive parenting than mothers with children with typical development (Maljaars, Boonen, Lambrechts, Van Leeuwen, \& Noens, 2014). This type of parenting is generally associated with the authoritative style, found in the present study. A study with 80 Israeli mothers, 40 of whom had children with ASD and the others with typical development children found that in regulating fearful behavior in children, the authoritative parenting style plays a more central role in the regulatory behavior of children with ASD (Hirschler-Guttenberg, Feldman, Ostfeld-Etzion, Laor, \& Golan, 2015). Probably the caregivers when answering about the child's behavior may have overestimated their children's prosocial behavior skills, because it is a divergent result in view of the diagnosis of this population. On the other hand, it is hypothesized for this result that the use of the authoritative style with the use of reinforcement strategies accompanied by affection and the establishment of consistent rules also increases the child's prosocial behavior skills.

Children in the fourth profile had many behavior problems and apparently do not have a behavioral repertoire that neutralizes these difficulties. The ASD population generally has both internalizing behavior problems (e.g., depression, anxiety, somatic complaints) and externalizing behavior problems (e.g., aggressiveness, hyperactivity and conduct problems) (Totsika et al., 2011). Other international investigations with parents of children with ASD compared to other populations of children also found that the ASD children exhibit a lower level of prosocial behavior (Saito et al., 2017; Totsika et al., 2011).

The divergences in the perception of the coparental relationship in the couple, especially with regard to conflict, support, parental agreement and the recognition of the partner's parenting and the low levels of proximity in this profile can favor the appearance or even the maintenance of behavioral difficulties of children with ASD. In addition, these characteristics of the coparental relationship do not favor the promotion of skills of prosocial behavior. On the other hand, it can be said that the behavior of these children may also influence the quality of the coparental relationship.

Regarding the coparental relationship, the mothers obtained high rates of agreement in parenting practices and acknowledgement of the partner's parenting - considered the highest when compared to the other profiles. In this sense, mothers realized that although their children had many behavioral problems, 
they manage to find a balance in parenting practices with their partner and they also have a tendency to recognize his efforts in the exercise of his parenting functions. This fact shows the satisfaction of the spouses with the performance of their partners in relation to their children care. This dimension concerns the positive recognition of one partner in relation to the parenting of the other and how much approval there is between spouses when they are exercising the role of parents (Feinberg, Brown, \& Kan, 2012).

In this group, both mothers and fathers demonstrated a perception of the parenting style as authoritarian, obtaining the highest mean when compared to the other profiles. Probably couples use the authoritarian style, mainly because they identify that their children have many behavior problems and few prosocial skills that minimize the damage caused by those difficulties. The adoption of an authoritarian parenting style with the excessive use of punishments and little affection can increase the conduct problems that involve the violation of social rules. Conduct problems are considered externalizing behavior problems and in the study of Ventola, Lei, Paisley, Lebowitz, and Silverman (2017) parents of children with ASD tend to respond to more disruptive behaviors with greater parental control, severe punishment and may be less tolerant; it can be said that these parenting practices would be associated with the authoritarian style.

One of the limitations of this investigation was the lack of control of the variable children ASD severity level, because due to the variability in the characteristics of the autistic spectrum such variability could influence the results of this survey. In addition, parents' mental health characteristics, such as parental stress, could be an important control variable for the investigation of parental and coparental relationships.

It is expected that the findings of this investigation be beneficial in some way to the professionals and parents of these children. Advancing behavioral interventions with family members is suggested, so that parents learn strategies of child's behavior management and can act in a more assertive manner and also encourage them to serve as a reference model of prosocial skills for children with ASD.

\section{Contributors}

J. R. M. PORTES participated in the data collection and analysis, discussion of the results and review of the final version. M. L. VIEIRA participated in the discussion of results and review of the final version. C. D. SOUZA participated in its data analysis, discussion of results and review of the final version, and E. KASZUBOWSKI assisted in data analysis, discussion of results and review of the final version of the article.

\section{References}

American Psychological Association. (2014). Manual diagnóstico e estatístico de transtornos mentais: DSM-V. Porto Alegre: Artmed.

Baumrind, D. (1991) The influence of parenting style on adolescent competence and substance use. Journal of Early Adolescence, 11(1), 56-95. http://dx.doi.org/10.1177/0272431691111004

Baykal, S., Karakurt, M. N., Çakır, M., \& Karabekiroğlu, K. (2018). An examination of the relations between symptom distributions in children diagnosed with autism and caregiver burden, anxiety and depression levels. Community Mental Health Journal, 55(2), 311-317. http://dx.doi.org/10.1007/s10597-018-0343-8

Bourke-Taylor, H., Howie, L., \& Law, M. (2010). Impact of caring for a school-aged child with a disability: understanding mothers' perspectives. Australian Occupational Therapy Journal, 57, 127-136. http://dx.doi.org/10.1111/j.1440-1630. 2009.00817.x

Boyd, M. J., lacono, T., \& McDonald, R. (2019). The perceptions of fathers about parenting a child with developmental disability: a scoping review. Journal of Policy and Practice in Intellectual Disabilities. http://dx.doi.org/10.1111/jppi.12287

Braunstein, V. L., Peniston, N., Perelman, A., \& Cassano, M. C. (2013). The inclusion of fathers in investigations of autistic spectrum disorders. Research in Autism Spectrum Disorders, 7, 858-865. http://dx.doi.org/10.1016/j.rasd.2013.03.005 
Camargo, S. P. H., \& Bosa, C. A. (2012). Competência social, inclusão escolar e autismo: um estudo de caso comparativo. Psicologia: Teoria e Pesquisa, 28(3), 315-324. http://dx.doi.org/10.1590/S0102-37722012000300007

Carvalho, T. R., Barham, E. J., Souza, C. D., Böing, E., Crepaldi, M. A., \& Vieira, M. L. (2018). Cross-cultural adaptation of an instrument to assess coparenting: coparenting relationship Scale. Psico-USF, 23(2), 215-227. http://dx.doi. org/10.1590/1413-82712018230203

Davys, D., Mitchell, D., \& Martin, R. (2017). Fathers of people with intellectual disability: a review of the literature. Journal of Intellectual Disabilities, 21, 175-196. http://dx.doi.org/10.1177/1744629516650129

Dunn, M. E., Burbine, T., Bowers, C. A., \& Tantless-Dunn, S. (2001). Moderators of stress in parents of children with autism. Community Mental Health Journal, 37, 39-52. http://dx.doi.org/10.1023/A:1026592305436

Faro, K. C. A., Santos, R. B., Bosa, C. A., Wagner, A., \& Costa Silva, S. S. (2019). Autismo e mães com e sem estresse: análise da sobrecarga materna e do suporte familiar. Psico, 50(2), e30080. http://dx.doi.org/10.15448/19808623.2019.2.30080

Feinberg, M. E. (2003). The internal structure and ecological context of coparenting: a framework for research and intervention. Parenting: Science and Practice, 3(2), 95-131. http://dx.doi.org/10.1207/S15327922PAR0302_01

Feinberg, M. E., Brown, L. D., \& Kan, M. L. (2012). A multi-domain self-report measure of coparenting. Parenting: Science and Practice, 12(1), 1-21. http://dx.doi.org/10.1080/15295192.2012.638870

Fleitlich, B., Cortázar, P. G., \& Goodman, R. (2000). Questionário de capacidades e dificuldades (SDQ). Infanto-Revista de Neuropsiquiatria da Infância e Adolescência, 8(1), 44-50.

Fombone, E. (2010). Epidemiology of autismo. Anais do $1^{\circ}$ Encontro Brasileiro para Pesquisa em Autismo, Porto Alegre.

Frosch, C. A., Schoppe-Sullivan, S. J., \& O'Banion, D. D. (2019). Parenting and child development: a relational health perspective. American Journal of Lifestyle Medicine, 22(2), 1-15. http://dx.doi.org/10.1177/1559827619849028

Gau, S. S., Chou, M., Lee, J., Wong, C., Chou, W., Chen, M., ... Wu, Y. (2010). Behavioral problems and parenting style among Taiwanese children with autism and their siblings. Psychiatry and Clinical Neurosciences, 64(1), 70-78. http:// dx.doi.org/10.1111/j.1440-1819.2009.02034.x

Hall, H. R., \& Graff, C. (2011). The relationships among adaptive behaviors of children with autism, family support, parenting stress, and coping. Issues in Comprehensive Pediatric Nursing, 34(1), 4-25. http://dx.doi.org/10.3109/014 60862.2011 .555270

Hirsch, K. H., \& Paquin, J. D. (2019). "The stress of the situation has changed us both": a grounded theory analysis of the romantic relationship of parents raising children with autism. Journal of Child and Family Studies, 28, 2673-2689. http://dx.doi.org/10.1007/s10826-019-01448-y

Hirschler-Guttenberg, Y., Feldman, R., Ostfeld-Etzion, S., Laor, N., \& Golan, O. (2015). Self- and co-regulation of anger and fear in preschoolers with autism spectrum disorders: the role of maternal parenting style and temperament. Journal of Autism and Developmental Disorders, 45, 3004-3014. http://dx.doi.org/10.1007/s10803-015-2464-z

James, G., Witten, D., Hastie, T., \& Tibshirani, R. (2013). Clustering Methods. In G. James, An introduction to statistical learning: with applications in $R$ (pp.385-396). New York: Springer.

Kersh, J., Hedvat, T. T., Hauser-Cram, P., \& Warfield, M. E. (2006). The contribution of marital quality to the well-being of parents of children with developmental disabilities. Journal of Intellectual Disability Research, 50(12), 883-893. http://dx.doi.org/10.1111/j.13652788.2006.00906.x

Maccoby, E. E., \& Martin, J. (1983). Socialization in the context of the family: parent-child interaction. In E. M. Hetherington \& P. H. Mussen (Ed.), Handbook of child psychology, socialization, personality and social development (pp.1-101). New York: Wiley.

Maljaars, J., Boonen, H., Lambrechts, G., Van Leeuwen, K., \& Noens, I. (2014). Maternal parenting behavior and child behavior problems in families of children and adolescents with autism spectrum disorder. Journal of Autism and Developmental Disorders, 44, 501-512. http://dx.doi.org/10.1007/s10803-013-1894-8

May, C., Fletcher, R. J., Dempsey, I., \& Newman, L. K. (2015). Modeling relations among coparenting quality, autism-specific parenting self-efficacy, and parenting stress in mothers and fathers of children with ASD. Parenting, 15(2), 119-133. http://dx.doi.org/10.1080/15295192.2015.1020145

May, C., George, J. M., Fletcher, R. J., Dempsey, I., \& Newman, L. K. (2017) Coparenting competence in parents of children with ASD: a marker of coparenting quality. Journal of Autism and Developmental Disorders, 47, 2969-2980. http:// dx.doi.org/10.1080/15295192.2015.1020145

Ministério da Saúde (Brasil). (2012). Portaria n 793, de 24 de abril de 2012. Institui a rede de cuidados à pessoa com deficiência no âmbito do Sistema Único de Saúde. Diário Oficial da União. Disponível em https://bvsms.saude.gov.br/ bvs/saudelegis/gm/2012/prt0793_24_04_2012.html 
Mosmann, C. P., Costa, C. B., Einsfeld, P., Silva, A. G. M., \& Koch, C. (2017). Conjugalidade, parentalidade e coparentalidade: associações com sintomas externalizantes e internalizantes em crianças e adolescentes. Estudos de Psicologia (Campinas), 34(4), 487-498. http://dx.doi.org/10.1590/1982-02752017000400005

Pedro, M. F., Carapito, E., \& Ribeiro, T. (2015). Parenting styles and dimensions questionnaire: versão portuguesa de autorrelato. Psicologia: Reflexão e Crítica, 28(2), 302-312. http://dx.doi.org/10.1590/1678-7153.201528210

Pereira, L. D., Canal, C. P. P., Corrêa, M. C. C. B., Silva, A. L. P., \& Pimentel, S. G. (2018). Dificuldades de mães e de pais no relacionamento com crianças com Transtorno do Espectro Autista. Contextos Clínicos, 11(3), 351-360. http:// dx.doi.org/10.4013/ctc.2018.113.06

Riany, Y. E., Cuskelly, M., \& Meredith, P. (2017). Parenting style and parent-child relationship: a comparative study of Indonesian parents of children with and without Autism Spectrum Disorder (ASD). Journal of Child and Family Studies, 26(12), 3559-3571. http://dx.doi.org/10.1007/s10826-017-0840-3

Riany, Y. E., Cuskelly, M., \& Meredith, P. (2019). Parenting style among Indonesian parents of children with Autism Spectrum Disorder: associations with socio-economic status and social supports. Journal of Developmental and Physical Disabilities, 31, 267-283. http://dx.doi.org/10.1007/s10882-018-9638-5

Saito, A., Stickley, A., Haraguchi, H., Takahashi, H., Ishitobi, M., \& Kamio, Y. (2017). Association between autistic traits in preschool children and later emotional/behavioral outcomes. Journal of Autism and Developmental Disorders, 47, 3333-3346. http://dx.doi.org/10.1007/s10803-017-3245-7

Sifuentes, M., \& Bosa, C. A (2010). Criando pré-escolares com autismo: características e desafios da coparentalidade. Psicologia em Estudo, 15(3), 477-485.

Sim, A., Cordier, R., Vaz, S., Netto, J., \& Falkmer, T. (2017). Factors associated with negative co-parenting experiences in families of a child with autism spectrum disorder. Developmental Neurorehabilitation, 20(2), 83-91. http://dx.doi. org/10.3109/17518423.2015.1069414

Siu, Q. K., Yi, H., Chan, R. C., Chio, F. H., Chan, D. F., \& Mak, W. W. (2019). The role of child problem behaviors in autism spectrum symptoms and parenting stress: a primary school-based study. Journal of Autism and Developmental Disorders, 49, 857-870. http://dx.doi.org/10.1007/s10803-018-3791-7

Thullen, M., \& Bonsall, A. (2017). Co-parenting quality, parenting stress, and feeding challenges in families with a child diagnosed with Autism Spectrum Disorder. Journal of Autism and Developmental Disorders, 47, 1-9. http://dx.doi. org/10.1007/s10803-016-2988-x

Totsika, V., Hastings, R. P., Emerson, E., Lancaster, G. A., \& Berridge, D. M. (2011). A population-based investigation of behavioural and emotional problems and maternal mental health: associations with autism spectrum disorder and intellectual disability. Journal of Child Psychology and Psychiatry, 52(1), 91-99. http://dx.doi.org/10.1111/j.1469-76 10.2010.02295.x

Ventola, P., Lei, J., Paisley, C., Lebowitz, E., \& Silverman, W. (2017). Parenting a child with ASD: comparison of parenting style between ASD, anxiety, and typical development. Journal of Autism and Developmental Disorders, 47, $2873-2884$. http://dx.doi.org/10.1007/s10803-017-3210-5

Woolfson, L., \& Grant, E. (2006). Authoritative parenting and parental stress in parents of pre-school and older children with developmental disabilities. Care, Health \& Development, 32(2), 177-184. http://dx.doi.org/10.1111/j.1365-22 14.2006.00603.x

World Health Organization (2017). Folha informativa: transtorno do espectro autista. Disponível em: https://www.paho. org/bra/index.php?Itemid=1098

Received: October 4, 2019

Final version: December 18, 2019

Approved: March 19, 2020 